\title{
Synthesis of a [5.5.5.5]Fenestrane via Pauson-Khand Reaction
}

\author{
Marc Thommen, Peter Gerber, and Reinhart Keese*
}

Abstract. A short synthesis of a functionalized [5.5.5.5]fenestrane is described.

Despite a variety of methods, which we and others have developed for the synthesis of [5.5.5.5]fenestranes, the chemistry of such tetracyclic compounds has hardly been explored $[1-4]$. This is mainly due to the fact, that our procedures leading to functionalized compounds, attractive for further transformations, are low-yield processes.

We now have found that functionalized [5.5.5.5]fenestranes can be prepared in good yield by a short route with the Pauson-Khand cyclization as the key step. This reaction has recently been shown to provide an efficient method for the preparation of a wide variety of cyclopentenones by Co-mediated reaction of an alkyne and an alkene with CO [5]. Schore and Knudsen demonstrated the wide applicability of the intramolecular variety of this method [6], and most recently Schreiber and coworker have reported conditions for efficient cyclizations at room temperature [7].

A retrosynthetic analysis reveals that the bicyclo[3.3.0]octene 2 with a butinyl side chain may be an appropriate starting material for the Pauson-Khand reaction to give a [5.5.5.5]fenestrane of type 1. From a simple thermochemical estimate, it can be concluded, that the formation of cyclopent-2enone form $\mathrm{HC} \equiv \mathrm{CH}, \mathrm{H}_{2} \mathrm{C}=\mathrm{CH}_{2}$ and $\mathrm{CO}$ is exothermic by $\mathrm{ca} .160 \mathrm{~kJ} / \mathrm{mol}$. Further deconvolution leads to a 2,5-disubstituted cyclopentanone 3. For the regio- and stereochemical control in the double alkylation, ethyl 2-oxocyclopentanecarboxylate (4) was eventually chosen as starting material.

\section{Results}

Deprotonation of 4 with $\mathrm{NaH}-\mathrm{BuLi}$ in THF at $-78^{\circ}$ and reaction with 4-iodobutyne lead to alkylation in $\gamma$-position of the $\beta$-keto ester. Subsequent alkylation of $\mathbf{5 a}$ with 3bromo-2-ethoxypropenyl phosphonate gave $\mathbf{5 b}$, which was hydrolyzed to give the keto phosphonate $5 \mathbf{c}$. Cyclization under phase transfer conditions lead to the bicyclic compound $\mathbf{6 a}$ as the predominant stereoisomer

* Correspondence: Prof. R. Keese

Institut fuir Organische Chemie

Universität Bern

Freiestrasse 3, $\mathrm{CH}-3012$ Bern in an overall yield of $34 \%$. Selective reduction of the $\mathrm{C}=\mathrm{O}$ group from the exo-side gave, after acetylation, $\mathbf{7 b}$ in $73 \%$.

Reaction of $7 \mathbf{b}$ with $\mathrm{Co}_{2}(\mathrm{CO})_{8}$ for $12 \mathrm{~h}$ lead upon addition of $\mathrm{N}$-methylmorpholine $\mathrm{N}$-oxide to the desired fenestrane 8 in $35-38 \%$.

\section{Structure Elucidation}

The structures of $\mathbf{6 a} \mathbf{a}, \mathbf{b}$ and $\mathbf{8}$ were established by detailed analysis of NMR spectra. The $\mathrm{C}, \mathrm{H}$ and $\mathrm{H}, \mathrm{H}$ correlations for the ring system and the substitutents of $6 \mathrm{a}$ were obtained from COSY and hetero-COSY measurements (Table 1). A ${ }^{1} \mathrm{H}_{3}{ }^{1} \mathrm{H}-\mathrm{NOE}$ analysis revealed the $c i s$-relationship between $\mathrm{H}-\mathrm{C}(4), \mathrm{H}-\mathrm{C}(7)$, and $\mathrm{H}-\mathrm{C}(8)$ on the endoside of the bicyclic ring system. ${ }^{13} \mathrm{C},{ }^{1} \mathrm{H}$ hetero-NOE results clearly showed, that $\mathrm{H}_{\text {exo }}-\mathrm{C}(4)$ and $\mathrm{H}_{\text {exo }}-\mathrm{C}(6)$ are on the same side with the EtOCO group [8].

The structure of 8 was apparent from the
${ }^{13} \mathrm{C}$ - and ${ }^{1} \mathrm{H}$-NMR spectra (Table 2). Based on the observation of a small coupling constant between $\mathrm{H}-\mathrm{C}(4)$ and $\mathrm{H}-\mathrm{C}(5)(J=2.9$ $\mathrm{Hz}$ ) and the $\mathrm{cis}$-relationship between $\mathrm{H}-\mathrm{C}(5)$ and $\mathrm{H}_{\text {ero }}-\mathrm{C}(6)$ (NOE results), it was concluded, that the $\mathrm{AcO}$ group is trans to the EtOCO group at $\mathrm{C}(7)$. Since NOE results reveal a cis-relationship between $\mathrm{H}-\mathrm{C}(4)$ and $\mathrm{H}-\mathrm{C}(10)$, the [5.5.5.5]fenestrane 8 belongs to the (all-cis)-series. The stereoisomerism in $[$ m.n.o.p]fenestranes has been already discussed [9].

\section{Discussion}

Several procedures have been proposed for high-yield Pauson-Khand reactions [5-7]. Usually the $\mathrm{Co}_{2}(\mathrm{CO})_{6}$-alkine complex is prepared prior to the thermal or amine oxide induced reaction. In our hands, thermal cyclizations with different functionalities in $\mathbf{6}$ and different solvents gave essentially no products [10] and clearly shows the superior modification found by Schreiber and coworkers [7].

Since it was unclear, whether the EtOCO group at the bridgehead position of $7 \mathrm{~b}$ would hamper the Pauson-Khand reaction, we decided to prepare 9a. With the ester group located at the endo-side of the bicyclic ring system and not, as in 6a at the exo-side, steric hindrance would be less during cyclization. Alkylation of 4 with 3-iodo-2ethoxypropenyl phosphonate gave $\mathbf{5} \mathbf{d}$ as a mixture of diastereoisomers in $27 \%$. Further alkylation with 4-bromobutyne gave $5 \mathrm{e}$ which was hydrolyzed to yield $\mathbf{5 f}$. When $\mathbf{5 f}$ was submitted to the same phase-transfer

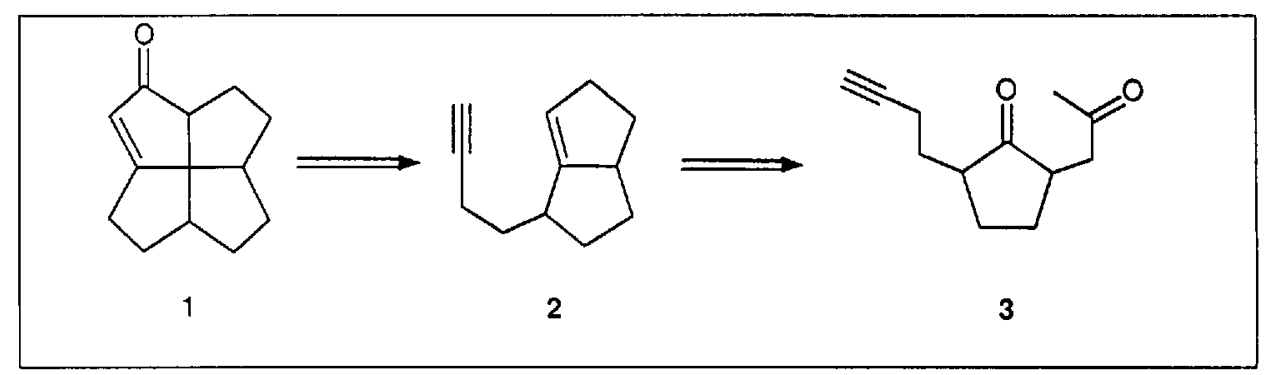

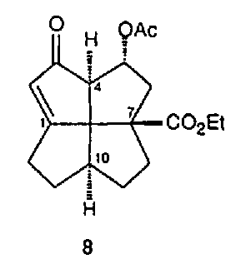
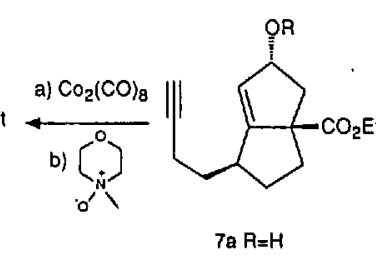

b $\mathrm{R}=\mathrm{COM}$

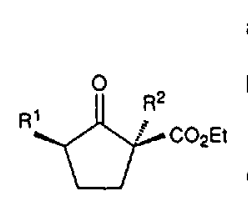

5

a $\begin{aligned} \mathrm{R}^{\prime} & =\mathrm{CH}_{2}-\mathrm{CH}_{2}-\mathrm{CaCH} \\ \mathrm{R}^{2} & =\mathrm{H}\end{aligned}$

b $\mathrm{A}^{1}-\mathrm{CH}_{2}-\mathrm{CH}_{2}-\mathrm{C}=\mathrm{CH}$ $\mathrm{R}^{2}=\mathrm{CH}_{2} \cdot \mathrm{C}=\mathrm{CH} \cdot \mathrm{P}\left(\mathrm{OM} \mathrm{M}_{2}\right.$

C $\mathrm{R}^{1}=\mathrm{CH}_{2}-\mathrm{CH}_{2} \mathrm{O}$ $\mathrm{R}^{1}=\mathrm{CH}_{2}-\mathrm{CH}_{2}-\mathrm{C}=\mathrm{CH}$
$\mathrm{R}^{2}=\mathrm{CH}_{2}-\mathrm{C}-\mathrm{CH}_{2}-\mathrm{P}(\mathrm{OM} \theta)_{2}$ If 0

$$
\text { (1) }
$$$$
\text { a) } 1 \mathrm{NHCl}
$$$$
\text { b) }\left(8 \mathrm{Bu}_{3} \stackrel{+}{\mathrm{N}} \mathrm{M} \theta \dot{\mathrm{O}} \mathrm{H}\right.
$$$$
\text { Toluene- } \mathrm{H}_{2} \mathrm{O}
$$

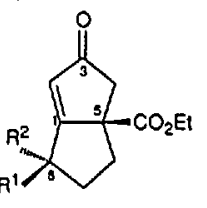

6a Ri= $\mathrm{CH}_{2}-\mathrm{CH}_{2}-\mathrm{C}=\mathrm{CH}, \mathrm{R}^{2}=\mathrm{H}$

D $\mathrm{R}^{1}=\mathrm{H}, \mathrm{R}^{2}=\mathrm{CH}_{2} \cdot \mathrm{CH}_{2} \cdot \mathrm{C}=\mathrm{CH}$ 
Table 1. NMR Data of $6 \mathbf{a}$

\begin{tabular}{|c|c|c|c|}
\hline Assignment & $\begin{array}{l}\left.{ }^{13} \text { C-NMR }{ }^{a}\right) \\
\delta[\mathrm{ppm}]\end{array}$ & $\begin{array}{l}\left.{ }^{(} \mathrm{H}-\mathrm{NMR}^{\mathrm{b}}\right)^{\mathrm{c}} \text { ) } \\
\delta[\mathrm{ppm}]\end{array}$ & $\begin{array}{l}{ }_{H}{ }_{H},{ }_{H} \\
\text { Connectivity }\end{array}$ \\
\hline$C(1)$ & $187.841(s)$ & - & - \\
\hline $\mathrm{H}-\mathrm{C}(2)$ & $127.970(d)$ & $6.10(d, 1.3)$ & $\mathrm{H}_{\mathrm{X}}-\mathrm{C}(4), \mathrm{H}-\mathrm{C}(8)$ \\
\hline$C(3)$ & $208.669(s)$ & - & - \\
\hline $\mathrm{CH}_{2}(4)$ & $48.661(t)$ & $\begin{array}{l}2.32\left(d, H_{n}, 17.3\right) \\
2.74\left(d, H_{x}, 17.3\right)\end{array}$ & $\begin{array}{l}\mathrm{H}_{\mathrm{x}}-\mathrm{C}(4) \\
\mathrm{H}-\mathrm{C}(2), \mathrm{H}_{\mathrm{n}}-\mathrm{C}(4)\end{array}$ \\
\hline$C(5)$ & $60.288(s)$ & - & - \\
\hline $\mathrm{CH}_{2}(6)$ & $33.578(t)$ & $\begin{array}{l}1.43(d d d, \mathrm{Hn} \\
12.2,12.2,8.5) \\
2.73\left(d d, \mathrm{H}_{\mathrm{x}}\right. \\
12.5,7.0)\end{array}$ & $\begin{array}{l}\mathrm{H}_{\mathrm{x}}-\mathrm{C}(6), \mathrm{CH}_{2}(7) \\
\mathrm{H}_{\mathrm{n}}-\mathrm{C}(6), \mathrm{CH}_{2}(7), \\
\mathrm{H}-\mathrm{C}(8)\end{array}$ \\
\hline $\mathrm{CH}_{2}(7)$ & $32.090(t)$ & $\begin{array}{l}1.55-1.84\left(m, \mathrm{H}_{x}\right) \\
2.23-2.34\left(m, \mathrm{H}_{\mathrm{n}}\right)\end{array}$ & $\begin{array}{l}\mathrm{CH}_{2}(6), \mathrm{H}_{\mathrm{n}}-\mathrm{C}(7), \mathrm{H}-\mathrm{C}(8) \\
\mathrm{CH}_{2}(6), \mathrm{H}_{\mathrm{X}}-\mathrm{C}(7), \mathrm{H}-\mathrm{C}(8)\end{array}$ \\
\hline $\mathrm{H}-\mathrm{C}(8)$ & $38.063(d)$ & $3.01-3.15(\mathrm{~m})$ & $\begin{array}{l}\mathrm{H}-\mathrm{C}(2), \mathrm{H}_{x}-\mathrm{C}(6) \\
\mathrm{CH}_{2}(7), \mathrm{CH}_{2}(12)\end{array}$ \\
\hline$C(9)$ & $172.930(s)$ & - & - \\
\hline $\mathrm{CH}_{2}(10)$ & $61.646(l)$ & $\begin{array}{l}4.11\left(d q, \mathrm{H}_{\mathrm{a}}\right. \\
10.7,7.0) \\
4.17\left(d q, \mathrm{H}_{\mathrm{b}}\right. \\
10.7,7.3)\end{array}$ & $\begin{array}{l}\mathrm{H}_{x}-\mathrm{C}(4), \mathrm{H}_{x}-\mathrm{C}(6) \\
\mathrm{CH}_{3}(1 \mathrm{l})\end{array}$ \\
\hline $\mathrm{CH}_{3}(11)$ & $14.015(q)$ & $1.22(t .3 \mathrm{H}, 7.0)$ & $\mathrm{CH}_{2}(10)$ \\
\hline $\mathrm{CH}_{2}(12)$ & $33.376(t)$ & $\begin{array}{l}1.62\left(d d t, \mathrm{H}_{\mathrm{a}},\right. \\
13.6,8.8,6.6) \\
1.75\left(d t d, \mathrm{H}_{\mathrm{b}}\right. \\
13.2,7.4,1.9)\end{array}$ & $\mathrm{H}-\mathrm{C}(8), \mathrm{CH}_{2}(13)$ \\
\hline $\mathrm{CH}_{2}(13)$ & $17.064(t)$ & $2.23-2.34(m, 2 \mathrm{H})$ & $\mathrm{CH}_{2}(12), \mathrm{H}-\mathrm{C}(15)$ \\
\hline$C(14)$ & $83.062(s)$ & - & - \\
\hline $\mathrm{H}-\mathrm{C}(15)$ & $69.426(d)$ & $2.01(t, 2.6)$ & $\mathrm{CH}_{2}(13)$ \\
\hline
\end{tabular}

NOE results: $\mathrm{H}-\mathrm{C}(2): \mathrm{H}_{\mathrm{n}}-\mathrm{C}(7), \mathrm{H}-\mathrm{C}(8) ; \mathrm{H}_{\mathrm{n}}-\mathrm{C}(4)$ : $\mathrm{H}-\mathrm{C}(2), \mathrm{H}_{\mathrm{x}}-\mathrm{C}(4), \mathrm{H}_{\mathrm{n}}-\mathrm{C}(6) ; \mathrm{H}_{\mathrm{n}}-\mathrm{C}(6): \mathrm{H}_{\mathrm{n}}-\mathrm{C}(4), \mathrm{H}_{\mathrm{x}}-\mathrm{C}(6)$, $\mathrm{H}_{\mathrm{n}}-\mathrm{C}(7), \mathrm{H}-\mathrm{C}(8) ; \mathrm{H}_{\mathrm{x}}-\mathrm{C}(6): \mathrm{H}_{\mathrm{n}}-\mathrm{C}(6) ; \mathrm{H}_{\mathrm{x}}-\mathrm{C}(7): \mathrm{H}_{\mathrm{n}}-\mathrm{C}(7) ; \mathrm{H}_{\mathrm{n}}-\mathrm{C}(7): \mathrm{H}_{\mathrm{n}}-\mathrm{C}(6), \mathrm{H}_{\mathrm{x}}-\mathrm{C}(7), \mathrm{H}-\mathrm{C}(8) ; \mathrm{H}-\mathrm{C}(8):$ $\mathrm{H}-\mathrm{C}(2), \mathrm{H}_{\mathrm{n}}-\mathrm{C}(6), \mathrm{H}_{\mathrm{n}}-\mathrm{C}(7), \mathrm{CH}_{2}(12) ; \mathrm{CH}_{2}(12): \mathrm{H}-\mathrm{C}(8), \mathrm{CH}_{2}(13)$

a) Multiplicity determined by DEPT. b) Assigned according to hetero-COSY ${ }^{c}$ ) Approximate multiplicity. $\left.{ }^{d}\right) \mathrm{COSY}$ results; $\mathrm{n}=$ endo, $\mathrm{x}=e . \mathrm{x} \sigma{ }^{1} \mathrm{H}-\mathrm{NOE}$ results are reported in the following way: $\mathrm{H}-\mathrm{C}(\mathrm{X})$ ira adiated [signal enhancement at $\mathrm{H}-\mathrm{C}(\mathrm{Y})]$.
C-PO $\left(\mathrm{OCH}_{3}\right)_{3}$ bond necessary for the synelimination and formation of the double bond is established in $\mathbf{1 0}$ and $\mathbf{1 1}$ as well.

The excess of $\mathrm{OH}^{-}$ions, provided by phase transfer and added to the phosphonate moiety might induce the hydrolysis of the ester group in 11 and $\mathbf{1 2}$. Steric crowding may prevent the interaction between the basic phopshono- and the ester group in $\mathbf{1 0 .}$

Given the high stability and the ready formation of lactones like 13 [11], the interaction of the two functionalities in $\mathbf{1 2}$ appears reasonable. Model considerations suggest, that an intramolecular reaction is also possible in 11. Base-induced en$d o \rightarrow e x o$-isomerization of the phosphono group in 12 might then lead to the $\gamma$-carboxysubstituted enone, which decarboxylates during workup to give upon preferential protonation from the exo-side $9 \mathbf{d}$ as the major isomer.

The observation, that 14 , which was obtained in high yield by pig-liver esterase reaction of the corresponding ethyl- resp. allylester, readily decarboxylates [12], corroborates the fast decarboxylation.

\section{Concluding Remarks}

The Pauson-Khand reaction provides an efficient route to a [5.5.5.5]fenestrane, appropriately functionalized for further transformation and exploration of the chemistry of this class of compounds. Further work in this area of the deformation space of tetracoordinate carbon is in progress.

This work was generously supported by the Swiss National Science Foundation (project No. 20-26220.89). conditions used for cyclization of $5 c$, a mixture $9 \mathrm{c} / 9 \mathrm{~d}$ instead of $9 \mathrm{a} / 9 \mathrm{~b}$ was obtained.

The structures of $9 \mathrm{c}$ and $9 \mathrm{~d}$ were deduced from ID- and 2D-NMR data. In 9c, the butinyl group is assigned to the exo-position, because a syn-relationship between the endo-H's at $\mathrm{C}(4), \mathrm{C}(6), \mathrm{C}(7)$, and $\mathrm{H}-\mathrm{C}(8)$ could be established by NOE results.

The endo-position of the butinyl side chain in 9d was also apparent from NOE data, which showed a syn-relationship between the endo-H's at C(4), C(6), and C(7) as well as between $\mathrm{H}_{e \times(O}-\mathrm{C}(7)$ and $\mathrm{H}-\mathrm{C}(8)$.

The unexpected removal of the EtOCO group during the cyclization reaction in the case of $5 \mathrm{f}$ but not in $\mathbf{5 c}$ may be due to the different arrangement of the phosphonate and the EtOCO group after cyclization but prior to the terminating step of the HornerEmmons reaction.

Model considerations reveal, that in $\mathbf{5 c}$ as well as in $\mathbf{5 f}$ the phosphono-enolate adds in the $\mathrm{C}=\mathrm{O}$ group in such a way, that cisbicyclo[3.3.0]octane structures like $\mathbf{1 0}$ and 11 and 12, respectively, are formed. The cis-relationship of the $\mathrm{C}-\mathrm{O}^{-}$and the<smiles>[R1]C1CC[C@@]([R2])(C(=O)OCC)C1=O</smiles>

5

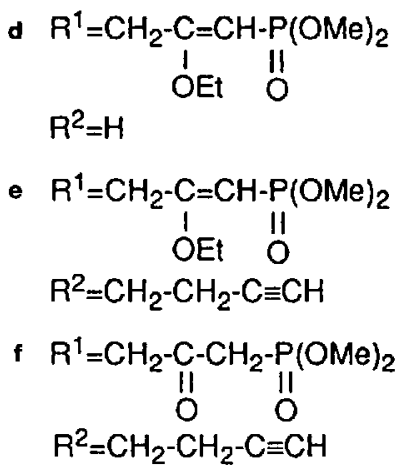

a $\mathrm{R}^{2}=\mathrm{CH}_{2}-\mathrm{CH}_{2}-\mathrm{C} \equiv \mathrm{CH}$ $\mathrm{A}^{3}=\mathrm{CO}_{2} \mathrm{Et}$

b $\mathrm{R}^{2}=\mathrm{CO}_{2} \mathrm{Et}$ $\mathrm{R}^{3}=\mathrm{CH}_{2}-\mathrm{CH}_{2}-\mathrm{C} \equiv \mathrm{CH}$

c $\mathrm{R}^{2}=\mathrm{CH}_{2}-\mathrm{CH}_{2}-\mathrm{C} \equiv \mathrm{CH}$ $\mathrm{R}^{3}=\mathrm{H}$

d $\mathrm{R}^{2}=\mathrm{H}$ $\mathrm{R}^{3}=\mathrm{CH}_{2}-\mathrm{CH}_{2}-\mathrm{C} \equiv \mathrm{CH}$ 
Table 2. NMR Data of 8

\begin{tabular}{|c|c|c|c|}
\hline Assignment & $\begin{array}{l}\left.{ }^{13} \mathrm{C}-\mathrm{NMR}^{21}\right) \\
\delta[\mathrm{ppm}]\end{array}$ & $\begin{array}{l}\left.\left.{ }^{\mathrm{l}} \mathrm{H}-\mathrm{NMR}^{\mathrm{b}}\right)^{\mathrm{c}}\right) \\
\delta[\mathrm{ppm}]\end{array}$ & $\begin{array}{l}{ }_{\mathrm{H}}{ }^{\mathrm{l}}{ }_{\mathrm{H}} \\
\text { Connectivityd }\end{array}$ \\
\hline $\mathrm{C}(\mathrm{I})$ & $187.031(s)$ & - & - \\
\hline $\mathrm{H}-\mathrm{C}(2)$ & $123.350(d)$ & $5.75(t, 1.1)$ & $\mathrm{CH}_{2}(12)$ \\
\hline$C(3)$ & $208.348(s)$ & - & - \\
\hline $\mathrm{H}-\mathrm{C}(4)$ & $66.759(d)$ & $2.92(d, 2.9)$ & $\mathrm{H}-\mathrm{C}(5), \mathrm{H}_{\mathrm{n}}-\mathrm{C}(6)$ \\
\hline $\mathrm{H}-\mathrm{C}(5)$ & $75.873(d)$ & $\begin{array}{l}5.45(d d d, \\
6.6,6.9,2.9)\end{array}$ & $\mathrm{H}-\mathrm{C}(4), \mathrm{CH}_{2}(6)$ \\
\hline $\mathrm{CH}_{2}(6)$ & $44.413(t)$ & $\begin{array}{l}1.87\left(d d, \mathrm{H}_{\mathrm{n}},\right. \\
14.3,6.0)\end{array}$ & $\mathrm{H}-\mathrm{C}(4), \mathrm{H}-\mathrm{C}(5), \mathrm{H}_{\mathrm{x}}-\mathrm{C}(6)$ \\
\hline & & $\begin{array}{l}2.81\left(d d, \mathrm{H}_{\mathrm{X}}\right. \\
14.3,6.6)\end{array}$ & $\mathrm{H}-\mathrm{C}(5), \mathrm{H}_{\mathrm{n}}-\mathrm{C}(6)$ \\
\hline$C(7)$ & $63.715(s)$ & - & - \\
\hline $\mathrm{CH}_{2}(8)$ & $34.679(t)$ & $\begin{array}{l}1.74-1.87\left(m, \mathrm{H}_{\mathrm{n}}\right) \\
2.41-2.54\left(m, \mathrm{H}_{\mathrm{X}}\right)\end{array}$ & $\begin{array}{l}\mathrm{CH}_{2}(9), \mathrm{H}-\mathrm{C}(10) \\
\mathrm{CH}_{2}(9), \mathrm{H}-\mathrm{C}(10)\end{array}$ \\
\hline $\mathrm{CH}_{2}(9)$ & $33.177(t)$ & $\begin{array}{l}1.74-1.87\left(m, \mathrm{H}_{\mathrm{x}}\right) \\
2.20-2.30\left(m, \mathrm{H}_{\mathrm{n}}\right)\end{array}$ & $\begin{array}{l}\mathrm{CH}_{2}(8), \mathrm{H}-\mathrm{C}(10) \\
\mathrm{CH}_{2}(8), \mathrm{H}-\mathrm{C}(10)\end{array}$ \\
\hline $\mathrm{H}-\mathrm{C}(10)$ & $46.279(d)$ & $2.54-2.64(\mathrm{~m})$ & $\begin{array}{l}\mathrm{CH}_{2}(8), \mathrm{CH}_{2}(9), \\
\mathrm{CH}_{2}(11)\end{array}$ \\
\hline $\mathrm{CH}_{2}(11)$ & $32.628(t)$ & $\begin{array}{l}1.74-1.87\left(m, \mathrm{H}_{\mathrm{x}}\right) \\
2.04-2.19\left(m, \mathrm{H}_{\mathrm{n}}\right)\end{array}$ & $\begin{array}{l}\mathrm{H}-\mathrm{C}(10), \mathrm{CH}_{2}(12) \\
\mathrm{H}-\mathrm{C}(10), \mathrm{CH}_{2}(12)\end{array}$ \\
\hline $\mathrm{CH}_{2}(\mathrm{I})$ & $28.266(t)$ & $2.41-2.57(m, 2 \mathrm{H})$ & $\mathrm{CH}_{2}(11)$ \\
\hline$C(13)$ & $75.430(s)$ & - & - \\
\hline$C(14)$ & $173.745(s)$ & - & - \\
\hline $\mathrm{CH}_{2}(15)$ & $61.033(t)$ & $4.04(q, 7,2 \mathrm{H})$ & $\mathrm{CH}_{3}(16)$ \\
\hline $\mathrm{CH}_{3}(16)$ & $13.840(q)$ & $1.20(t, 7,3 \mathrm{H})$ & $\mathrm{CH}_{2}(15)$ \\
\hline $\mathrm{C}(17)$ & $170.099(s)$ & - & - \\
\hline $\mathrm{CH}_{3}(18)$ & $21.126(q)$ & $2.065(s, 3 \mathrm{H})$ & \\
\hline
\end{tabular}

NOE results: $\mathrm{H}-\mathrm{C}(4)$ : $\mathrm{H}-\mathrm{C}(2), \mathrm{H}-\mathrm{C}(5), \mathrm{H}-\mathrm{C}(\mathrm{I} 1) ; \mathrm{H}-\mathrm{C}(5): \mathrm{H}-\mathrm{C}(4), \mathrm{H}_{\mathrm{x}}-\mathrm{C}(6) ; \mathrm{H}_{\mathrm{x}}-\mathrm{C}(6): \mathrm{H}-\mathrm{C}(4), \mathrm{H}-\mathrm{C}(5), \mathrm{H}_{\mathrm{n}^{-}}$ $\mathrm{C}(6) ; \mathrm{H}-\mathrm{C}(10): \mathrm{H}-\mathrm{C}(4), \mathrm{H}_{\mathrm{n}}-\mathrm{C}(9), \mathrm{H}_{\mathrm{n}}-\mathrm{C}(11)$.

a) Multiplicity determined by DEPT. b) Assigned according to hetero-COSY. ${ }^{\mathrm{c}}$ ) Approximate multiplicity. ${ }^{\text {d) }} \mathrm{COSY}$

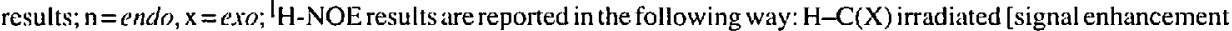
at $\mathrm{H}-\mathrm{C}(\mathrm{Y})]$.

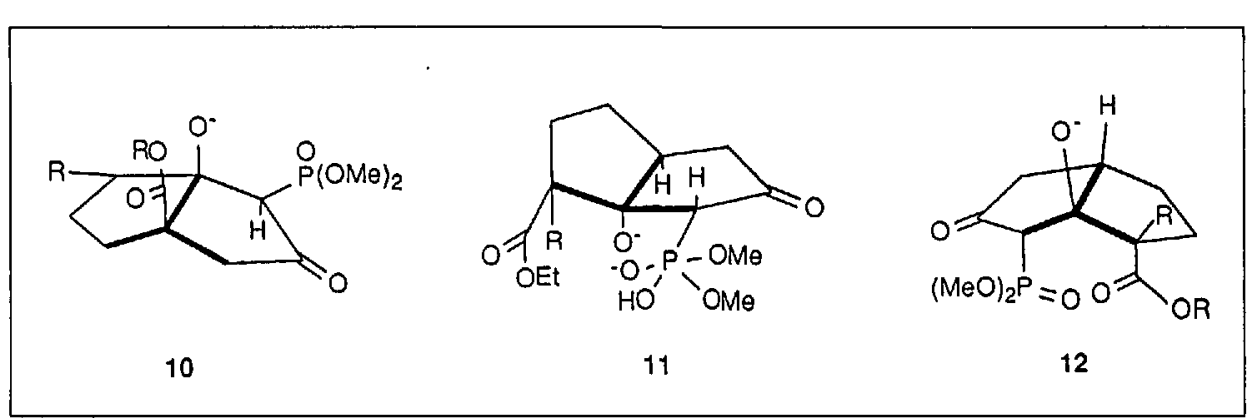

\section{Experimental Part}

General. See [1]. Workup procedure: the reaction mixture was poured onto crushed ice, if necessary neutralized, resp., acidified and extracetd $3 \times$ with $\mathrm{Et}_{2} \mathrm{O}$ The $\mathrm{Et}_{2} \mathrm{O}$ extract was dried $\left(\mathrm{MgSO}_{4}\right)$ and gave upon cvaporation crude product. HPLC conditions: Lichrosorb Si $60,7 \mu \mathrm{m}, 24 \mathrm{~cm}$; GC conditons: (l) Column: cross-linked dimethylsilicone, $12.5 \mathrm{~m}$, temp. program: $T_{1}=40^{\circ}+3^{\circ} / \mathrm{min}, T_{2}=300^{\circ}$; (2) column: $S E 54,20 \mathrm{~m}$, temp. program: $T_{1}=40^{\circ}+3 \% \mathrm{~min}, T_{2}=250^{\circ}$. NMR spectral were obtained in $\mathrm{CDCl}_{3}$ using Bruker $A F 300$ and $A M 400$ instruments; sequence of data: $\delta$ [ppm] (mulitplicity, coupling constants in $\mathrm{Hz}$, number of H's). MS spectra: the $m / z 100 \%$ peak is underlined.

Ethyl 3-(But-3-inyl)-2-orocyclopentanecarboxylate (5a) [13]. A soln. of $8.00 \mathrm{~g}(0.051 \mathrm{~mol})$ of ethyl 2 -oxocyclopentanecarboxylate (4) in $100 \mathrm{ml}$ of THF
CHIMIA 45 (1991) Nr.1/2 (Jinuliar/Fithruar)

(61\%) of a red oil containing 5 as mixture of diastereoisomers. $R_{\mathrm{f}}\left(\mathrm{AcOEt} / \mathrm{CH}_{3} \mathrm{OH}\right.$ 99:1) 0.71. IR: 3310 , 1755, 1720. ' $\mathrm{H}-\mathrm{NMR}: 1.23-1.36(2 t, 3 \mathrm{H}) ; 1.40-1.64$ $(m, 2 \mathrm{H}) ; 1.72-2.52(\mathrm{~m}, 7 \mathrm{H}) ; 1.98(\mathrm{l}, 2.5,2 \mathrm{H}) ; 3.16(\mathrm{dd}$, $8.3,11.4,0.60 \mathrm{H}) ; 3.29(d d, 4.4,8.8,0.30 \mathrm{H}) ; 4.12-4.28$ $(m, 2 \mathrm{H}) . \mathrm{MS}: 208\left(M^{+}\right), 207,180,163,156,134,110$, 108 .

Ethyl8-exo-(But-3-inyl)bicyclo[3.3.0/ort-l-ene-5carbotylate (6). To a suspension of $0.53 \mathrm{~g}(0.013 \mathrm{~mol})$ of $\mathrm{NaH}$ in $130 \mathrm{ml}$ of THF was slowly added a soln. of $2.4 \mathrm{~g}(0.012 \mathrm{~mol})$ of $5 \mathrm{a}$ in $20 \mathrm{ml}$ of THF, followed by addition of $4.1 \mathrm{~g}(0.015 \mathrm{~mol})$ of dimethyl-3-bromo-2ethoxypropenyl phosphonate [14] in $20 \mathrm{ml}$ of THF. After stirring for $12 \mathrm{~h}$ at RT., the mixture was worked up and extracted with AcOEt to give $5.7 \mathrm{~g}$ of $\mathbf{5 b}$ as an orange oil. Crude $\mathbf{5 c}$, obtained after treatment of $\mathbf{5 b}$ with $9 \mathrm{ml}$ of $1 \mathrm{~N} \mathrm{HCl}$ in $250 \mathrm{ml}$ of acetone for $90 \mathrm{~min}$ and appropriate workup, was dissolved in $140 \mathrm{ml}$ of toluene $/ \mathrm{H}_{2} \mathrm{O} \quad 1: \mathrm{l}$ and stirred with $6.5 \mathrm{ml}(0.012 \mathrm{~mol})$ of $\mathrm{Bu}_{3} \mathrm{~N}^{+} \mathrm{CH}_{3} \mathrm{OH}^{-}$for $12 \mathrm{~h}$. The oily crude material obtained after separation of the aq. phase and removal of the solvent, was chromatographed (hexane/Et? O3:2) to give $1.47 \mathrm{~g}(52 \%)$ of $6 \mathrm{a}$ and $6 \mathrm{~b}(85: 15)$. This mixture was separated by HPLC (hexane/ $/$-BuOMe $9: 1$ ). Pure 6a was obtained by recrystallization from $t$ - BuOMe 6 a.

6a: m.p. $40.5^{\circ}, R_{\mathrm{f}}$ (hexane/Et $\left.{ }_{2} \mathrm{O} 4: 6\right) 0.46$. HPLC: $k^{\prime}=11.61 . \mathrm{GC}(1): 43.15 \mathrm{~min}$. IR: $3310,1720,1640$, 1265, 1170 . ' $\mathrm{H}$ - and ${ }^{13} \mathrm{C}-\mathrm{NMR}$ : see Table /. MS: 246 $\left(M^{+}\right), 218,217,174,173,145,144,133,117$. Anal.calc. for $\mathrm{C}_{15} \mathrm{H}_{18} \mathrm{O}_{3}$ (246.31): $\mathrm{C} 73.15, \mathrm{H}$ 7.37; found: $\mathrm{C}$ $73.13, \mathrm{H} 7.10$.

6b: $R_{\mathrm{f}}$ (hexane/Et $\left.{ }_{2} \mathrm{O} 4: 6\right)$ 0.46. HPLC: $k^{\prime}=13.44$. GC (1): $44.05 \mathrm{~min} . \mathrm{IR}: 3310,1725,1710,1630 . \mathrm{I}_{\mathrm{H}-}$ NMR: $1.23(t, 8.4,3 \mathrm{H}) ; 1.45-\mathrm{I} .72(\mathrm{~m}, 3 \mathrm{H}) ; 1.95-2.10$ $(m, 1 \mathrm{H}) ; 2.01(t, 2.1,1 \mathrm{H}) ; 2.23-2.52(m, 3 \mathrm{H}) ; 2.31(\mathrm{~d}$, $18.2, \mathrm{I} \mathrm{H}) ; 2.66(d d, 12.1,7.1, \mathrm{I} \mathrm{H}) ; 2.92(d, 18.2, \mathrm{I} \mathrm{H})$; $2.98-3.11(\mathrm{~m}, 1 \mathrm{H}) ; 4.16(\mathrm{dq}, 10.1 .8 .4,2 \mathrm{H}) ; 5.97(\mathrm{~d} .0 .5$, $1 \mathrm{H}) .{ }^{13} \mathrm{C}-\mathrm{NMR}: 14.02(q) ; 17.09(t) ; 30.56(t) ; 31.80$ $(t) ; 32.39(t) ; 37.37(d) ; 48.11(t) ; 60.16(s) ; 61.73(t)$; $69.27(d) ; 83.19(s) ; 124.65(d) ; 172.97(s): 189.21(s) ;$ 208.53 (s). MS: $246,218,189,179,173,145,144,133$, $131,129$.

Erhyl 3-endo-Hydroxy-8-exo-(but-3-ingl)hicydt)[3.3.0]oct-1-ene-5-exo-carborylate (7a). To al soln. of $3.072 \mathrm{~g}(8.25 \mathrm{mmol})$ of $\mathrm{CeCl}_{3} \cdot 7 \mathrm{H}_{2} \mathrm{O}$ in $80 \mathrm{ml}$ of $\mathrm{CH}_{3} \mathrm{OH}$ were added $2.00 \mathrm{~g}(8.13 \mathrm{mmol})$ of $6 \mathrm{a}$ and $0.33 \mathrm{~g}(8.67$ mmol) of $\mathrm{NaBH}_{4}$ [15]. Workup gave $2.8 \mathrm{~g}$ of a yellowish oil, which was purified by low-bar chromatogralphy (hexane/t-BuOMe $1: 1$ ) to give $1.81 \mathrm{~g}(90 \%)$ of $7 \mathrm{a}$ as an oil. $R_{\mathrm{f}}$ (hexane/Et2O 1:1) 0.29. IR: 3620,3600, $3410,1722,1182,1025 .{ }^{1} \mathrm{H}-\mathrm{NMR}: 1.24(t, 7,3 \mathrm{H}) ; 1.33-$ $\mathrm{I} .48(m, 1 \mathrm{H}) ; 1.4-1.58(m, 2 \mathrm{H}) ; 1.54(d d, 12.5,7.36$, ( H); $160-177(m, 1 \mathrm{H}) ; 1.77(1 \mathrm{H}) ; 1.94(1,2.6,1 \mathrm{H})$; $2.15-2.28(m, 3 \mathrm{H}) ; 2.43-2.51(d d, 12.1,7.35, \mathrm{I} \mathrm{H})$; 2.7-2.84 (m, I H); 2.80 (dd, 12.5, 6.25,1 H); 4.11 (du, $2 \mathrm{H}) ; 5.38(\mathrm{~m}, \mathrm{l} \mathrm{H}) ; 5.61(\mathrm{dcl}, \mathrm{l} \mathrm{H}) .{ }^{13} \mathrm{C}-\mathrm{NMR}$ : $155.3(\mathrm{~s}$, $\mathrm{C}(1)) ; 128.15(s, \mathrm{C}(2)) ; 82.54(d,(\mathrm{C}(3)) ; 49.7(t,(\mathrm{C}(4))$; $64.6(s, \mathrm{C}(5)) ; 35.68(t, \mathrm{C}(6)) ; 33.59(t, \mathrm{C}(7)) ; 36.16(d$, $\mathrm{C}(8)) ; 175.7\left(s, \mathrm{C}\left(1^{\prime}\right)\right) ; 60.8\left(t, \mathrm{C}\left(2^{\prime}\right)\right) ; 14.14\left(q . \mathrm{C}\left(3^{\prime}\right)\right)$; $33.92\left(t, \mathrm{C}\left(\mathrm{l}^{\prime \prime}\right)\right) ; 17.0 \mathrm{l}\left(t, \mathrm{C}\left(2^{\prime \prime}\right)\right) ; 84.0 \mathrm{I}\left(\mathrm{s}, \mathrm{C}\left(3^{\prime \prime}\right)\right) ; 68.60$ $\left(d, \mathrm{C}\left(4^{\prime \prime}\right)\right)$. MS: $248\left(M^{+}\right), 176,175,174,146,145,133$, $132,131$.

Ethyl 3-endo-Acetoxy-8-exo-(but-3-inyl)hicyclo[3.3.0]oct-1-cne-5-exo-carborylate (7b). Freshly distilled $\mathrm{CH}_{3} \mathrm{COBr}(2.45 \mathrm{~g}, 19.96 \mathrm{mmol})$ was added to a soln. of $1.65 \mathrm{~g}(6.65 \mathrm{mmol})$ of $7 \mathrm{a}$ in $90 \mathrm{ml}$ ether and 1.58 $\mathrm{g}(19.96 \mathrm{mmol})$ of pyridine at $0^{\circ}$. After stirring for $14 \mathrm{~h}$, the reaction mixture was worked up and gave after lowbar chromalography $1.58 \mathrm{~g}(82 \%)$ of $7 \mathrm{~b}$ as viscous oil. which solidifies at $c a .-15^{\circ} . R_{\mathrm{f}}$ (hexane/Et $\left.2 \mathrm{O} 1: 1\right) 0.73$. IR: $3310,1725,1375$. ' $\mathrm{H}$-NMR: $1.24(t, 7.0,3 \mathrm{H}) ; 1.34$ $1.62(\mathrm{~m}, 3 \mathrm{H}) ; 1.71(\mathrm{dd}, 12.9 .7 .4,1 \mathrm{H}) ; 1.62-1.79(\mathrm{~m}$, $1 \mathrm{H}) ; 1.95(t, 2.7,1 \mathrm{H}) ; 2.05(\mathrm{~s}, 3 \mathrm{H}) ; 2.17-2.31(\mathrm{~m} .3 \mathrm{H})$; 2.48-2.54 (ddd, 13, 12, 7.35, I H); 2.73-2.86 (m, l H); $2.80(d d, 12.9,6.3,1 \mathrm{H}) ; 4.10(d q, 10.7 .1 \mathrm{H}) ; 4.15(d d$, $10,7,1 \mathrm{H}) ; 5.59(d d, 1 \mathrm{H}) ; 6.13(d d d, 7.4,6.2,1 \mathrm{H}) . \mathrm{MS}$ : $290\left(M^{+}\right), 248,217,216,203,202,175,174,157,146$, 142, 132.

Pauson-Khand Reaction of $7 \mathbf{b}$. A mixlure of 0.462 $\mathrm{g}(1.6 \mathrm{mmol}) 7$ and $0.653 \mathrm{~g}(1.72 \mathrm{mmol})$ of $\mathrm{CO}_{2}(\mathrm{CO})_{8}$ was stirred in $30 \mathrm{ml}$ of $\mathrm{CH}_{2} \mathrm{Cl}_{2}$ for $14 \mathrm{~h}$ to give a red soln. Upon addition of $1.23 \mathrm{~g}(10.5 \mathrm{mmol})$ of $N$-methylmorpholino $\mathrm{N}$-oxide the soln., which turned brownishviolet, was stirred for $24 \mathrm{~h}$ at RT. After addition of 50 $\mathrm{ml}$ of $\mathrm{Et}_{2} \mathrm{O}$, the soln. was centrifuged and concentrated. Low-bar chromatography with hexane/AcOEt 2:1 gave 
$0.192 \mathrm{~g}(34 \%)$ of a yellowish oil, from which crystals could be obtained in petroleum ether. Recrystallization gave white crystals of 8 . M.p. $77^{\circ}$. $R_{\mathrm{f}}$ (hexane/AcOE 2:1) 0.49. IR: 1740, 1725, 1239. ${ }^{1} \mathrm{H}-$ and ${ }^{13} \mathrm{C}-\mathrm{NMR}: c f$ Table 2. MS: $318\left(58, M^{+}\right), 276(32), 275(82), 259(34)$ 258 (100), $230(91), 201$ (54), $184(50), 157$ (54). Anal. calc. for $\mathrm{C}_{18} \mathrm{H}_{22} \mathrm{O}_{5}$ (318.37): $\mathrm{C} 67.91, \mathrm{H} 6.97$; found: $\mathrm{C}$ $68.14, H 7.08$

Ethyl3-[2-Ethoxy-3-(dimethylphosphono)prop-2 enyll-2-oxocyclopentanecarborylate (5d). To a soln of $0.065 \mathrm{~mol}$ of LDA, prepared from $31.0 \mathrm{ml}$ of $2.095 \mathrm{M}$ $\mathrm{BuLi}$ in hexane and $6.58 \mathrm{~g}(0.065 \mathrm{~mol})$ of (i-Pr ${ }_{2} \mathrm{NH}$ was added a soln. of $5 \mathrm{~g}$ ( $32 \mathrm{mmol}$ ) of 2-ethoxycarbonylcyclopentanone 4 in $10 \mathrm{ml}$ of $\mathrm{THF}$ at $-70^{\circ}$. After warming and stirring at $0^{\circ}$ for $1 \mathrm{~h}$, the mixture was cooled to $-70^{\circ}$ and a soln. of $8.8 \mathrm{~g}(0.032 \mathrm{~mol})$ of dimethyl (3-bromo2-ethoxypropenyl)phosphonate [14] was added. Stirring for $30 \mathrm{~min}$ at $-70^{\circ}$ and for $12 \mathrm{~h}$ at RT. and workup with $\mathrm{AcOEt}$ gave an oil, which was purified by flash chromatography ( $\mathrm{AcOEt} / \mathrm{CH}_{3} \mathrm{OH} 20: 1$ ) to give $2.51 \mathrm{~g}$ $(27 \%)$ of $5 \mathbf{d}$ as a $2.3: 1$ mixture of diastereoisomers Major isomer: $R_{\mathrm{f}}\left(\mathrm{AcOEt} / \mathrm{CH}_{3} \mathrm{OH} 20: 1\right) 0.21$. IR: 1755 1725,1612 . ' $\mathrm{H}-\mathrm{NMR}: 1.26-1.38(2 t, 7.0,7.4,6 \mathrm{H})$ $1.59-1.76(\mathrm{~m}, \mathrm{I} \mathrm{H}) ; 2.08-2.28(\mathrm{~m}, 2 \mathrm{H}) ; 2.28-2.40(\mathrm{~m}$ $1 \mathrm{H}) ; 2.51-2.68(\mathrm{~m}, 1 \mathrm{H}) ; 2.81(\mathrm{ddd}, 14.3,8.5,1.5,1 \mathrm{H})$ $3.03($ ddd $, 14.2,5.2,1.5,1 \mathrm{H}) ; 3.19$ (ddd, $10.7,8.1,1 \mathrm{H})$ $3.7(d d, 11.4,1.8,6 \mathrm{H}) ; 3.82(4.7 .0,2 \mathrm{H}) ; 4.22(q .7 .4$ $2 \mathrm{H}) ; 4.48(d, 5.9,1 \mathrm{H}) .13 \mathrm{C}-\mathrm{NMR}: 13.5(q) ; 13.8(q)$ $24.6(t) ; 25.9(t) ; 31.9(t) ; 46.4(d) ; 51.61(q) ; 51.64(q)$ $54.2(d) ; 60.8(t) ; 63.5(t) ; 82.9(d d, 206.7) ; 169.1(d)$ $172.1(s d, 22.9) ; 211.1(s)$.MS: $348\left(M^{+}\right), 302,273,229$ 220, 193, 165, 151, 137,83. Minor isomer: ${ }^{3} \mathrm{C}-\mathrm{NMR}$ $13.5(q) ; 13.7(q) ; 24.4(q) ; 26.4(t) ; 32.2(t) ; 46.2(d)$ $51.48(q) ; 51.50(q) ; 53.4(t) ; 54.2(t) ; 63.47(t) ; 83.6(d d$ $205.6) ; 168.6(s) ; 172.2(s d, 22.9)$.

Eihyl 1-(But-3-iny) ()-3-12-ethoxy-3-(dimethylphosphonolprop-2-enylJ-2-oxocyclopentanecar hoxylate (5e). The solid $\mathrm{K}^{+}$salt, prepared from $2.0 \mathrm{~g}$ $(5.8 \mathrm{mmol})$ of $5 \mathrm{~d}$ and $0.36 \mathrm{~g}$ of $82 \% \mathrm{KH}(7.4 \mathrm{mmol})$ in $40 \mathrm{ml}$ of THF was after removal of the solvent dissolved in $40 \mathrm{ml}$ of DMSO, treated with $1.080 \mathrm{~g} \mathrm{(6} \mathrm{mmol)} \mathrm{of} 4$ iodobut-1-yne and stirred for $24 \mathrm{~h}$. After workup and low-bar chromatography $0.94 \mathrm{~g}$ of $\mathbf{5 d}$ and $0.59 \mathrm{~g}$ (49\% based on turnover of $5 d$ ) of $5 e$ as a $3: 1$ mixture of diastercoisomers were obtained. Majorisomer: $R_{\mathrm{f}}$ (AcOEt/ $\left.\mathrm{CH}_{3} \mathrm{OH} 20: 1\right) 0.38$. IR: $3310,1750,1725,1620 .{ }^{1} \mathrm{H}$ NMR: $1.25-1.34(2 t, 7.0,6 \mathrm{H}) ; 1.27-1.36(\mathrm{~m}, 1 \mathrm{H}) ; 1.80$ $1.93(m, 2 \mathrm{H}) ; 1.97(m, 1 \mathrm{H}) ; 2.04-2.20(m, 2 \mathrm{H}) ; 2.20$ $2.28(m, 1 \mathrm{H}): 2.28-2.40(m, 1 \mathrm{H}) ; 2.40-2.54(m, 1 \mathrm{H})$ $2.54-2.67(m .1 \mathrm{H}) ; 2.77(d d, 8.8,1.0,1 \mathrm{H}) ; 2.94$ (ddd
$14.0,4.1,1.5,1 \mathrm{H}) ; 3.70(d d, 11.4,1.8,6 \mathrm{H}) ; 3.81(q, 7.0$, $2 \mathrm{H}) ; 4.20(q, 70,2 \mathrm{H}) ; 4.46(d, 6.3,1 \mathrm{H}) \cdot{ }^{13} \mathrm{C}-\mathrm{NMR}$ $14.0(q) ; 14.1(q) ; 14.4(t) ; 26.3(t) ; 33.4(t) ; 32.1(t) ; 33.5$ $(t) ; 47.1(d) ; 51.9(q) ; 52.1(q) ; 59.8(s) ; 61.6(t) ; 63.8(t)$ $68.9(d) ; 83.1(d d, 207.4) ; 83.4(s) ; 170.5(s) ; 172.8(s d$ 22.5); $214.0(s)$. MS: $400\left(M^{+}\right), 281,165,151,137,84$ 83. Minor isomer: ${ }^{3} \mathrm{C}-\mathrm{NMR}: 14.0(q) ; 14.1(q) ; 14.4$ $(t) ; 25.0(t) ; 30.5(t) ; 32.6(t) ; 32.1(t) ; 46.5(d) ; 52.0(q)$ $59.6(d) ; 61.5(t) ; 68.9(d) ; 83.3(d d, 207.4) ; 83.4(s) ; 170.9$ $(q) ; 172.8(s d, 22.5) ; 213.4(s)$.

Ethyl 2-(But-3-inyl)-2-oxo-3-[2-oro-3-(dimethyphosphono)propyl]cyclopentanecarboxylate (5f). A soln. of $0.60 \mathrm{~g}(1.5 \mathrm{mmol})$ of $5 \mathrm{e}$ in $10 \mathrm{ml}$ of $\mathrm{CH}_{2} \mathrm{Cl}_{2}$ and $20 \mathrm{ml}$ of $70 \% \mathrm{CF}_{3} \mathrm{COOH}$ was refluxed for $45 \mathrm{~min}$. After treatment with sat $\mathrm{NaHCO}_{3}$ soln and evaporation of $\mathrm{CH}_{2} \mathrm{Cl}_{2}$ the crude product was purified by low-bar chromatography ( $\mathrm{ACOEv} / \mathrm{CH}_{3} \mathrm{OH} 20: 1$ ) to give $0.45 \mathrm{~g}$ $(81 \%)$ of $\mathbf{5 f}$ as a $1.1: 1$ mixture of diastereoisomers.

Isomer a: $R_{\mathrm{f}}\left(\mathrm{AcOEt} / \mathrm{CH}_{3} \mathrm{OH} 20: 1\right) 0.25$. IR: 3310 $1750,1725 .{ }^{1} \mathrm{H}-\mathrm{NMR}: 1.26(t, 7.0,3 \mathrm{H}) ; 1.62($ ddd, 12.5 $5.2,1.2,1 \mathrm{H}) ; 1.80-1.94(m, 1 \mathrm{H}) ; 1.98(t, 2.2,1 \mathrm{H}) ; 2.0$ $2.37(m, 5 \mathrm{H}): 2.55(\mathrm{dd}, 12.9 .6 .3,1 \mathrm{H}) ; 2.62-2.92(\mathrm{~m}$ $2 \mathrm{H}) ; 3.12(d, 22.8,2 \mathrm{H}) ; 3.05-3.18(m, 1 \mathrm{H}) ; 3.79(d t$ $11.4,2.2,6 \mathrm{H}) ; 4.18(q, 7.0,2 \mathrm{H}) .{ }^{13} \mathrm{C}-\mathrm{NMR}: 14.1(q)$; $14.3(t) ; 26.7(t) ; 31.4(t) ; 33.4(t) ; 41.5(t d, 127.8) ; 44.5$ $(d) ; 44.8(t) ; 53.1(q) ; 53.2(q) ; 59.7(s) ; 61.6(t) ; 69.1$ $(d) ; 83.2(s) ; 170.3(s) ; 199.4(s) ; 214.3(s) ; \mathrm{MS}: 372\left(M^{+}\right)$, $320,153,151,124,87,85,83$.

Isomer b: ${ }^{13} \mathrm{C}-\mathrm{NMR}: 14.0(q) ; 14.4(t) ; 25.3(t) ; 30.9$ $(t) ; 32.2(t) ; 41.4(d d, 127.8) ; 43.7(t) ; 44.5(d) ; 53.0(q) ;$ $53.1(q) ; 59.1(s) ; 61.6(d) ; 68.8(d) ; 83.7(s) ; 171.0(s)$ $199.4(s) ; 213.6(s)$.

8 -(But-3-inyl)bicyclo[3.3.0]oct-1-en-3-one $(9 \mathrm{c}, \mathrm{d})$ A mixture of $0.635 \mathrm{~g}(1.71 \mathrm{mmol})$ of $5 \mathrm{f}$ and $2 \mathrm{ml}$ of $40 \%$ (Bu) ${ }_{4} \mathrm{~N}^{+} \mathrm{OH}^{-}(3.0 \mathrm{mmol})$ in $40 \mathrm{ml}$ of toluene $/ \mathrm{H}_{2} \mathrm{O} 1$ : was vigorously stirred at $\mathrm{RT}$. for $18 \mathrm{~h}$. After neutralization with $2 \mathrm{~N} \mathrm{HCl}$ and extraction with $\mathrm{CH}_{2} \mathrm{Cl}_{2}$, the crude product was purified by low-bar chromatography (pentane/Et2O 5:2) to give $0.16 \mathrm{~g}(54 \%)$ of $9 \mathrm{c}$ and $9 \mathrm{~d}$ as a $1: 9$ mixture of diastereoisomers. Preparative GC(Carbon'a. $\left.20 \%, 43 \mathrm{~cm}, 160^{\circ}\right)$ provided $9 \mathrm{c}$ and $9 \mathrm{~d}$ in pure form.

9c: $R_{\mathrm{f}}$ (pentane/Et $\mathrm{O}$ 5:2) 0.22. GC (2):36.95 min. IR: $3310,1710,1650.1 \mathrm{H}-\mathrm{NMR}: 1.13-1.35(\mathrm{~m}, 2 \mathrm{H})$ $1.48-1.62(m, 2 \mathrm{H}) ; 1.65-1.75(\mathrm{~m}, 1 \mathrm{H}) ; 1.88-2.0(\mathrm{~m}, 1$ H); $2.0(t, 2.8,1 \mathrm{H}) ; 2.08(d d, 18.0,3.3,1 \mathrm{H}) ; 2.14-2.22$ $(m, 1 \mathrm{H}) ; 2.24-2.37(m, 2 \mathrm{H}) ; 2.62$ (ddd $18.0,6.6,0.8,1$ H); 2.89-3.08 $(m, 2 \mathrm{H}) ; 5.90(t, 2.0,1 \mathrm{H}) .{ }^{13} \mathrm{C}-\mathrm{NMR}: 17 . \mathrm{l}$ $(t) ; 29.5(t) ; 31.4(t) ; 32.2(t) ; 37.7(d) ; 42.6(t) ; 46.1(d) ;$ $69.1(d) ; 83.4(s) ; 123.5(d) ; 194.1(s) ; 210.8(s)$ MS $174\left(M^{+}\right), 146,132,131,118,117,105,104,91$. 9d: $R_{\mathrm{f}}$ (pentane/El $\left.2 \mathrm{O} 5: 2\right) 0.17 . \mathrm{GC}(2): 35.98 \mathrm{~min}$. IR $: 3310,1700,1650$ IH-NMR: 1.18 (ddd $122,7.7,1$ $\mathrm{H}) ; 1.58-1.69(\mathrm{~m}, 1 \mathrm{H}) ; 1.69-1.86(\mathrm{~m}, 2 \mathrm{H}) ; 2.02(t, 2.6$, $\mathrm{I} \mathrm{H}) ; 2.11$ (ddd, 17.6, 2.9, 1.5, $1 \mathrm{H}) ; 2.20(\mathrm{ddl}, 12.1,6.6$, I H); 2.29-2.36 $(m, 3 \mathrm{H}) ; 2.62(d d, 17.6,6.3,1 \mathrm{H}) ; 2.89$ $3.0(m, 1 \mathrm{H}) ; 3.01(0,7.7,1 \mathrm{H}) ; 5.9(1,1.8,1 \mathrm{H}),{ }^{13} \mathrm{C}-\mathrm{NMR}$ : $17.0(t) ; 30.9(t) ; 33.2(t) ; 33.5(t) ; 38.1(d) ; 42.4(t) ; 45.6$ $(d) ; 69.2(d) ; 83.3(s) ; 125(d) ; 192.9(s) ; 211.0(s)$. MS: $174\left(M^{+}\right), 146,133,131,118,117,105,104,91$.

Received: December 11, 1990

[1] a) J. Mani, S. Schuttel, C. Zhang, P. Bigler, C. Müller, R. Keese, Helv. Chim. Acta 1989, 72,487; b) R. Keese, 'Organic Synthesis: Modem Trends', Ed. O. Chizhov, Blackwell Scientific Publ., Oxford, 1987, p. 43.

[2] R. Mitschka, J.Ohldrich, K. Takahashi, U. Weiss, J.V. Silverton, J.M. Cook, Tetrahedron 1981,37, 4521 .

[3] B.R. Venepalli, W.C. Agosta, Chem. Rev. 1987, 87, 399 .

14] R. Keese, W. Luef, J. Mani, S. Schuttel, M. Schmid, C. Zhang, 'Strain and its Implications in Organic Chemistry', Eds. A. de Meijere and S. Blechert , Kluwer Academic Publ., 1989, p. 283.

[5] a) P.L. Pauson. Terahedron 1984, 40, 5855; b) P.L. Pauson, 'Organometallics in Organic Synthesis', Eds. A. de Meijere and H. tom Dieck, Springer Verlag, Berlin, 1987, p. 233.

[6] N.E. Schore, M.J. Knudsen, J.Org. Chem. 1987 , 52,569 .

[7] S. Shambayati, W.E. Crowe, S.L. Schreiber, Tetrahedron Lett. $1990,5289$.

[8] P. Bigler, unpublished results.

[9] W. Luef, R. Keese, Hels. Chim. Acta 1987, 70, 547

10] M. Thonmen, Diploma Thesis, University Bern. in preparation.

[11] R. Keese, A. Pfenninger, A. Roesle, Hell. Chim. Acla 1979, 62, 326.

[12] B. Stofer Vogel, D. Bourgin, R. Keese, unpublished results.

[13] E.M. Kaiser, J.D.Peity,P.L.A. Knutson, Symthesis 1977, 509.

[14] E. Piers, B. Abeysekera, Cam.J.Chem. 1982, 60, 1114

[15] J.-L. Luche, J. Am. Chem. Soc, 1978, 100, 2226.
Chimia 45 (1991) 24-27

(c) Schweiz. Chentikej-Verband; ISSN 0009-4293

\section{Synthese und Abfangen eines hochgespannten Cyclopropens ${ }^{* *}$}

\author{
Michel Mühlebach [1] und Markus Neuenschwander*
}

Abstract. Two synthetic sequences towards tricyclo[3.2.1.02,4]octa-2(4),6-diene (12) have been investigated starting with 1,1,2-tribromo-2-(trimethylsilyl)cyclopropane (13) (Schemes $l$ and 2$). \mathrm{F}^{-}$-induced elimination $13 \rightarrow \mathbf{1 4 a}$ and reaction with cyclopentadiene gives tricyclic dibromo precursor 15a in a $87 \%$ yield. Subsequent reaction of $15 \mathrm{a}$ with $t$-BuLi produces the highly strained cyclopropene 12 which has been trapped by [4+2] cycloaddition with diphenylisobenzofuran ( $40 \%$ yield). NMR-spectroscopic evidence of 2,4-disubstituted tricyclo[3.2.1.02,4]oct-6-enes $\mathbf{1 5 a}$, 15b, and $\mathbf{1 6}$ (Table) is briefly discussed.

\section{Einleitung}

Gespannte Moleküle haben den organischen Chemiker seit langem fasziniert. Cyclopropene zählen zu den einfachsten
Molekülen, welche eine beträchtliche Ringspannung aufweisen. Sie sind deshalb sowohl bindungstheoretisch wie spektroskopisch von erheblichem Interesse, jedoch als einfache reaktive $\mathrm{C}_{3}$-Synthesebausteine auch synthetisch attraktiv [2]. Leider werden synthetische Anwendungen und spektroskopische Untersuchungen durch die hohe thermische Instabilität der unsubstituierten Cyclopropene eingeschränkt. Bicyclische Cyclopropene mit aussergewöhnlichen Bindungsverhältnissen gewinnt man formal beim Ersatz der beiden Vinyl-H-Atome durch eine kurze AlkylKette. Theoretische Berechnungen zeigen nämlich, dass die olefinischen Substituenten der Bicyclen 1-4 nicht in einer Ebene liegen [3]. Dies lässt auf eine hohe Reaktivität der zentralen $(\mathrm{C}=\mathrm{C})$-Bindung schliessen. Tat-

\footnotetext{
* Korespondenz: Prof. Dr. M. Neuenschwander Institut für organische Chemie Universitat Bern

Freiestrasse 3, $\mathrm{CH}-3012$ Bern

** Dicse Arbeit wurde teilweise durch den Schu'eizerischen Nationalfonds zur Förderumg der wissenschaftlichen Forschung (Projekt Nr. 20-26167.89)
} unterstützt. 